\title{
FROST HARDINESS OF INTRODUCED SEA BUCKTHORN (Hippophae rhamnoides L.) GENOTYPES IN CENTRAL RUSSIA
}

\author{
Zoya Ozherelieva\#, Pavel Prudnikov, and Natalia Bogomolova \\ Federal State Budget Scientific Institution, All Russian Research Institute of Fruit Crop Breeding (FGBNU VNIISPK), \\ 302530 Orel region, Zhilina, RUSSIA \\ info@ vniispk.ru \\ \# Corresponding author
}

Communicated by Dalija Seglina

\begin{abstract}
Sea buckthorn (Hippophae rhamnoides L.) genotypes of different ecological and geographical origins were tested. Frost hardiness extent was determined during winter by artificial freezing, which allowed identify varietal differences in frost hardiness of buds and tissues of sea buckthorn shoots. In order to identify differences in adaptation to low temperature we determined the fractional composition of water in annual shoots; and proline and malone dialdehyde concentration and total amylase activity in bark of shoots of female and male genotypes. In December, the sea buckthorn genotypes were in deep dormancy, when maximum frost hardiness of buds and tissues of annual shoots occurred. During the next months, the frost hardiness of buds and shoot tissues decreased during the state of exogenous dormancy. The performed experiment gave an opportunity to select hardy genotypes 'Kenigsbergskaya', 'Surpriz Baltiki', B 23-34, and 'Prima Dona' for use in further breeding, as they had demonstrated stable hardiness during the whole winter period according to all of the components of winter hardiness.
\end{abstract}

Key words: sea buckthorn, artificial freezing, fractional water composition, proline, amylase, lipid peroxidation, frost resistance.

\section{INTRODUCTION}

Winter hardy cultivars play a crucial role in sea buckthorn (Hippophae rhamnoides L.) introduction into cultivation in the middle zone of Russia (Fiofelov, 2011). In the temperate zone of Russia, sea buckthorn with its short period of dormancy shows lower winter hardiness due to frequent thaws in winter (Selekhov et al., 2003). The frost resistant condition of plants is reached only in growth stops, entering dormancy and passing hardening phases (Turina, 2002; Koshkin, 2010; Kichina, 2011). Metabolic processes like starch hydrolysis, sugar and proline accumulation, and water outflow through membranes due to increase of lipid unsaturation, occur in plants during hardening (Mittler, 2002; Ashraf and Foolad, 2007; Genisel et al., 2013; Khorshidi and Sherafatmandjour, 2013).

Evaluation of the initial material for winter hardiness is an important stage in sea buckthorn breeding. At present, artificial freezing is a popular method of plant winter hardiness evaluation. Winter hardiness components were studied in apple (Alojzy et al., 2004; Cline et al., 2012; Ozherelieva and Sedov, 2014), raspberry (Ozherelieva and Bogomolova, 2011), sour and sweet cherry (Chmir, 2003), cherry plum and apricot (Szalay et al., 2010). Studies of physiological and biochemical processes under plant adaptation to nega- tive temperatures are mainly performed on cereals and perennial herbals (Bergjord et al., 2008; Yousfi et al., 2010; Ahmad et al., 2013; Genisel et al., 2013; Polevoi et al., 2015). There are no complex studies of physiological and biochemical processes and frost hardiness dynamics of introduced sea buckthorn plants to low temperature stresses in the temperate zone of Russia. Hence, study of adaptability indices of introduced plants and estimation of their resistance to unfavorable temperature stresses are of great importance.

The aim of the research was to study some physiological and biochemical indices and dynamics of frost resistance of introduced sea buckthorn genotypes to low temperature stress in different periods of winter.

\section{MATERIALS AND METHODS}

Artificial freezing of sea buckthorn plants was conducted in the "Espec" PSL-2KPH climatic chamber according to methods described previously (Turina et al., 2002). The basic components of hardiness were studied: component II maximum value of frost resistance under $-38^{\circ} \mathrm{C}$ developed by plants during hardening; component III - the ability to retain the hardened condition under $-25{ }^{\circ} \mathrm{C}$ after a period of 
three-day thaw $+2{ }^{\circ} \mathrm{C}$; component IV — the ability to restore frost resistance under $-30{ }^{\circ} \mathrm{C}$ after repeated hardening and three-day thaw $+2{ }^{\circ} \mathrm{C}$. The used hardening regime was $-5{ }^{\circ} \mathrm{C}$ during five days and $-10{ }^{\circ} \mathrm{C}$ during five days. For the tests, annual shoots were cut in 5-fold replication for each temperature and placed into plastic bags. The experimental material was kept at a temperature of $-3 \ldots-5{ }^{\circ} \mathrm{C}$. The duration of freezing was for eight hours. The temperature was lowered by $5{ }^{\circ} \mathrm{C}$ per hour.

Cold injury was evaluated by growing of shoots in vessels with water. The annual shoots were cut at base $(2-3 \mathrm{~cm}$ segment) after each freezing and placed in vessels with water at $+21 \pm 1{ }^{\circ} \mathrm{C}$ for ten days. The water was changed each couple of days.

The degree of bud damage was evaluated on a scale of 0 to 5; where $0=$ no damage; 1 = insignificant damage, the mesophyll under the bud was damaged; 2 = reversible damage, a part of the leaf bud was damaged; 3 = moderate damage, vascular system and most of leaf buds were damaged; 4 = severe damage, apical meristems and most of leaf buds were dead, and 5 = buds and tissues were dead.

Bark and wood (xylem) damage were evaluated according to tissue browning on longitudinal and cross-sections according to the following scale: $0=$ no damage, tissues were light-coloured; 1 = insignificant damage, $10-12 \%$ of tissue area was brown; $2=$ reversible damage, $20-40 \%$ of tissue area was brown; 3 = moderate damage, $40-60 \%$ of tissue area was brown; $4=$ severe damage, $60-80 \%$ of tissue area was brown and $5=>80 \%$ of tissue area was dead. A binocular microscope MBS-2 was used for evaluation of bud and tissue injury.

Fractional composition of water in one-year shoots of sea buckthorn was determined according to the OkuntzovaMarinchik method (Baslavskaya and Trubetzkova, 1991). Two $\mathrm{ml}$ of $30 \%$ of saccharose solution added to weighed phials. The phials with the solution were weighed and $0.4 \mathrm{~g}$ of tissue of an annual shoot was dipped into each phial, which causes transport of water from the tissue to the solution, reducing its concentration. In two hours the concentration of this solution was estimated. Differences of the concentrations was used to determine the quantity of available water transported to the solution from the tissue of the annual shoot. The concentration of bound water was calculated from the difference between the amount of total water and available water transported to the solution. The concentration of saccharose was determined on a digital refractometer PAL-1 "Ocawa" (Japan).

The concentration of tested substances were determined using a spectrophotometer BioRad SmartSpec Plus (USA). The proline content in the bark of shoots was determined by reaction with ninhydrin reagent (Bates et al., 1973). IBark samples $(500 \mathrm{mg}$ ) were ground in distilled water and boiled in a water bath for ten minutes. Then $2 \mathrm{ml}$ of the extract was taken and $2 \mathrm{ml}$ of concentrated acetic acid and $2 \mathrm{ml}$ of ninhydrin reagent $\left(30 \mathrm{ml}\right.$ of icy $\mathrm{CH}_{3} \mathrm{COOH}+20 \mathrm{ml} 6 \mathrm{M}$
$\mathrm{H}_{3} \mathrm{PO}_{4}+1.25 \mathrm{~g}$ of ninhydrin) were added, with subsequent boiling in a water bath for 1 hour. The amino acid concentration was calculated by calibrated curve for pure proline solutions at wave length $520 \mathrm{~nm}$. The proline concentration was expressed as micromole per $1 \mathrm{~g}$ of raw mass. The activity of lipid peroxidation (LPO) was estimated by the concentration of finite POL product in bark tissues - malone dialdehyde (MDA) on the basis of the qualitative reaction with thiobarbituric acid. $500 \mathrm{mg}$ of plant material was ground in $10 \mathrm{ml} 0.35 \mathrm{M} \mathrm{NaCl}$ and in $1 \mathrm{ml}$ trisHCl buffer $(\mathrm{pH}$ $8)$. The reagent $2 \mathrm{ml}(0.5 \%$ thiobarbituric acid $+20 \%$ trichloroacetic acid) was added to $3 \mathrm{ml}$ extract. Test-tubes with the solution were placed in boiling water bath for 30 minutes. After cooling the samples were filtered and the filtrate was analysed on the spectrophotometer at wave length $520_{\mathrm{nm}}$. MDA concentration was calculated based molar coefficient of extinction $1.56 \cdot 10^{5} \mathrm{M}^{-1} \cdot \mathrm{cm}^{-1}$. The MDA concentration was expressed as $\mu \mathrm{mol} / \mathrm{g}$ of raw mass (Stalnaya and Garishvili, 1977).

To determine total amylase activity, $1 \mathrm{~g}$ of plant material was ground in $10 \mathrm{ml}$ of $1 \% \mathrm{NaCl}$, followed by sedimentation for 30 minutes in a centrifuge "Jouan" MR1812 (Germany) at 5000 revolutions per minute. The supernatant was used as ferment extract. To determine the activity of the ferment, an incubation mixture consisting of $3 \mathrm{ml}$ acetate buffer with $\mathrm{pH} 5.5$ and $3 \mathrm{ml} 2 \%$ starch solution was prepared in test-tubes. The mixture was heated to $40{ }^{\circ} \mathrm{C}$ and $1 \mathrm{ml}$ of the ferment preparation was placed in each testtube. In control tubes, distilled water was added instead of the ferment preparation. The solutions were incubated in a thermostat "Binder" BD23 (Germany) for 1 hour at $40{ }^{\circ} \mathrm{C}$. After the incubation, $2 \mathrm{ml}$ of $1 \mathrm{~N} \mathrm{HCl}$ solution was added to each tube to stopping amylase activity. Reaction with iodine was used to determining concentration of starch that had not reacted. $30 \mathrm{ml}$ of water, $1 \mathrm{ml}$ of $0.1 \mathrm{~N} \mathrm{HCl}$ and 5 drops of $0.3 \%$ iodine solution were poured in measured retorts (50 $\mathrm{ml}$ ) and $1 \mathrm{ml}$ of incubated mixture was added from each tube. The retort contents were completely mixed and water was added to volume. Optical density was estimated at $\lambda=$ $595_{\mathrm{nm}}$. The amylase activity per $1 \mathrm{~g}$ of planting material for 1 hour was calculated according to the formula

$x=\frac{\left(D-D_{1}\right) a V}{D n V_{1}}$,

where $\mathrm{D}$ is optical density of the control solution; $\mathrm{D}_{1}$ - optic density of the experimental solution; a - quantity of added starch $(60 \mathrm{mg}) ; \mathrm{n}$ - weight mass, $\mathrm{g} ; \mathrm{V}$ - volume of the initial ferment extract, $\mathrm{ml}$; and $\mathrm{V}_{1}$ — volume of the extract taken for incubation, ml. The ferment activity was expressed in $\mathrm{mg}$ of hydrolyzed starch per $1 \mathrm{~g}$ of weight (Ermakov et al., 1987).

Several additional experimental variants were carried out to determine physiological and biochemical response of sea buckthorn plants to the effect of hardening, frost, and thaw. Biochemical testing was carried out on shots at various stages: Variant 1 ("shoots with buds in the phase of green cone"), annual shoots from the orchard were placed in ves- 
sels with water for growing at $\mathrm{t} 22 \pm 1^{\circ} \mathrm{C}$, and as the buds smelled the biochemical analysis was made; Variant 2 ("shoots without hardening") — shoots in dormancy that had not passed hardening in laboratory conditions $\left(-5{ }^{\circ} \mathrm{C}\right.$ during 5 days, $-10{ }^{\circ} \mathrm{C}$ during 5 days); Variant 3 ("shoots after hardening") — shoots in dormancy that had passed hardening in laboratory conditions; Variant 4 ("shoots after hardening and freezing at $-38{ }^{\circ} \mathrm{C}$ ") — shoots that had passed hardening and freezing in laboratory conditions at $-38{ }^{\circ} \mathrm{C}$ (Component II).

The experimental data were processed by methods of mathematical statistics (Dospekhov, 1985) and correlation analysis (Zaitzev, 1984) using MS Excel.

Sea buckthorn genotypes of various ecological and geographical origins from the All Russian Research Institute of Fruit Crop Breeding (VNIISPK) collection plantations were investigated: Baltic climatype cultivars 'Zheltoplodnaya', 'Zolotaya Kosa', 'Kenigsbergskaya', 'Serafima', 'Surpriz Baltiki' and male forms AB 10-154, B 23-34; Siberian climatype 'Baikal', 'Prima Dona', 'Ranniy Stolovy', and 'Startovaya', Siberian male form No. 1.

\section{RESULTS}

Two female cultivars — 'Zheltoplodnaya', 'Surpriz Baltiki' and two male genotypes - Siberian male form No. 1 and B 23-34 were examined for physiological and biochemical in- dices. Late in November, a high proportion of bound water to available water was noted in studied sea buckthorn genotypes: from 3.1 in 'Zheltoplodnaya' to 7.2 in Siberian male form No. 1. In one-year shoots the relative amounts of available water was $6.6-18.7 \%$ and $36.6-47.5 \%$ of bound water, respectively (Fig. 1).

High correlation occurred between bound and available water in tissue of annual shoots $(r=-0.77)$ when the plants were passing hardening and there was no significant difference between varieties in this trait $\left(\mathrm{F}_{\text {fact }}<\mathrm{F}_{\text {theor }}\right)$ in that period. Later, there was a significant difference in the relative content of available and bound water $\left(\mathrm{F}_{\text {fact }}=576.2>\right.$ $\mathrm{F}_{\text {theor0.01 }}=7.2$ ) and significant interaction of the variety and water fractions $\left(\mathrm{F}_{\text {fact }}=2.9>\mathrm{F}_{\text {theor } 0.01}=2.7\right)$.

The proline content was determined after the second phase of hardening. The analysis showed high concentration of that amino acid in bark tissue of Siberian male form No. 1 and Baltic climatype cultivar 'Zheltoplodnaya'. After temperature decrease to $-38{ }^{\circ} \mathrm{C}$ (Component II), the proline concentration decreased by $40 \%$ in Siberian male form No. 1 and by $43 \%$ in 'Zheltoplodnaya'. In contrast, insignificant decrease of proline concentration (9.0..3.5\%) was observed in shoots of 'Surpriz Baltiki' and B 23-34, which confirmed more stable frost resistance (Fig. 2). ANOVA indicated significant intervarietal differences in proline concentration in bark of annual shoots after hardening $\left(\mathrm{F}_{\text {fact }}=\right.$ $\left.807.0>\mathrm{F}_{\text {theor } 0.01}=9.8\right)$ at $p<0.01$. Significant intervarietal difference in the proline concentration was also found in

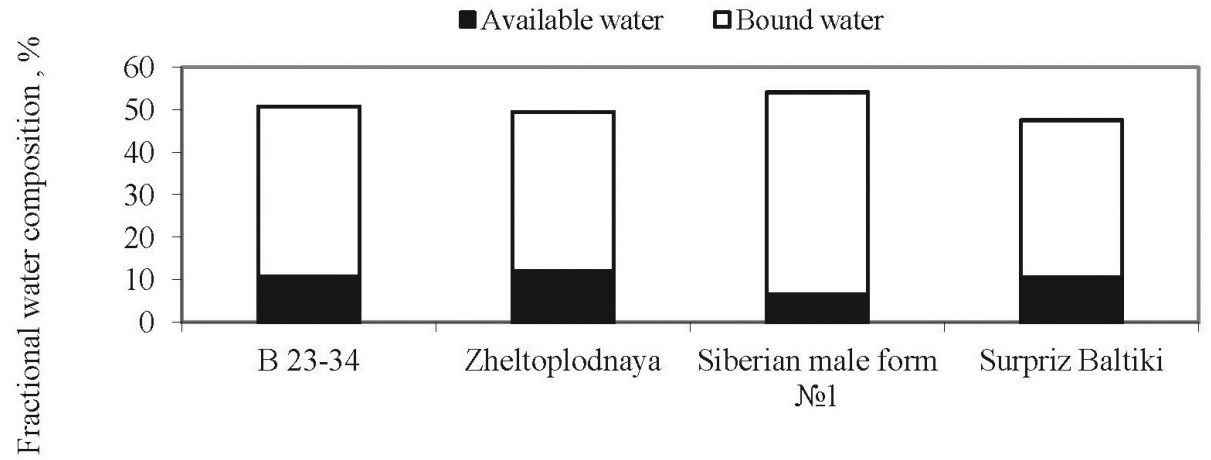

Genotypes

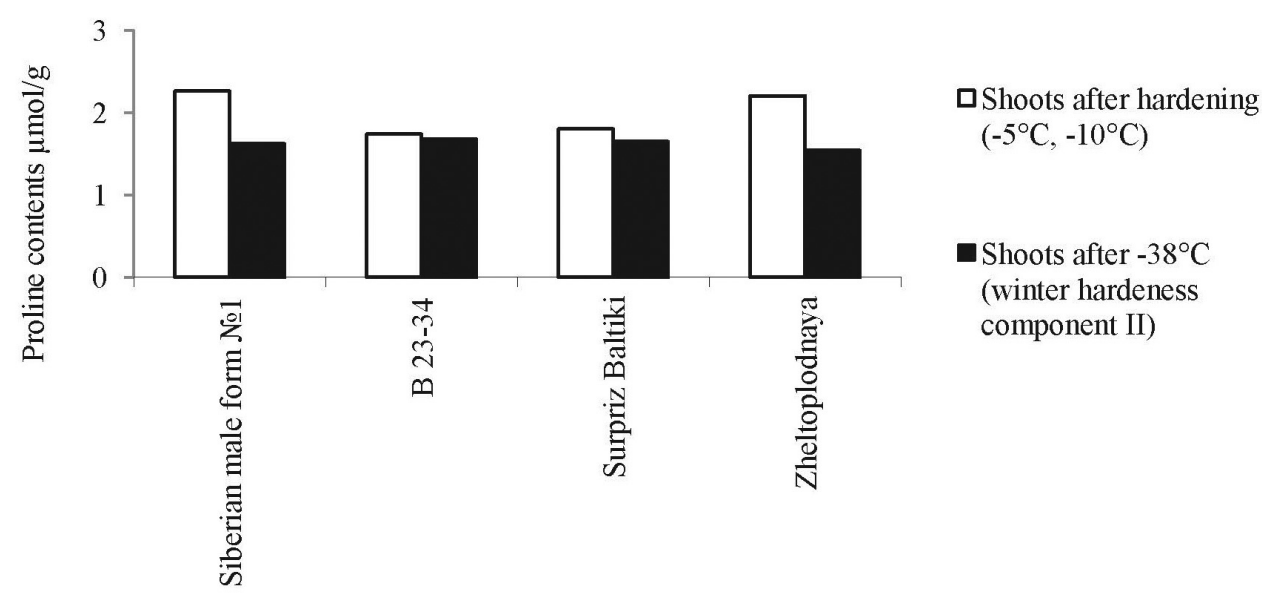

Fig. 1. Fractional water composition in sea buckthorn shoots late in November, $\%$.
Fig. 2. Proline concentration in sea buckthorn bark tissue in December, $\mu \mathrm{mol} / \mathrm{g}$. 
bark of annual shoots after freezing at $\mathrm{t}-38{ }^{\circ} \mathrm{C}$ (Component II) $\left(\mathrm{F}_{\text {fact }}=145.0>\mathrm{F}_{\text {theor0.01 }}=98\right)$ (Fig. 2).

In order to determine the maximum frost resistance during different winter periods (December, January, February) the artificial freezing of annual shoots of 12 variety samples was carried out at $-38{ }^{\circ} \mathrm{C}$ (Component II).

Baltic climatype cultivars 'Zheltoplodnaya', 'Zolotaya Kosa', 'Serafima', 'Surpriz Baltiki', AB 10-154 and Siberian climatype cultivar "Prima Dona" showed high frost hardiness of buds under $-38{ }^{\circ} \mathrm{C}$ temperature (winter hardiness component II). Baltic climatype cultivars 'Kenigsbergskaya' and B 23-34, Siberian climatype cultivar 'Startovaya' and Siberian form No. 1 had reversible injures of buds, up to 2.0 points. Buds of Siberian climatype cultivar 'Ranniy Stolovy' were severely damaged in December (3.2 points). In January all of the genotypes showed frost hardiness of buds (damages until 2.0 points) with the exception of the 'Ranniy Stolovy' and 'Startovaya' cultivars (damages 3.2-3.3 points). 'Zheltoplodnaya', 'Kenigsbergskaya', 'Prima Dona', 'Serafima', Siberian male form No. 1, AB 10-154, and B 24-34 had reversible injures of buds (until 2.0 points). A middle level of bud resistance was noted in 'Zolotaya Kosa' and 'Surpriz Baltiki', damage recorded at 2.2 to 2.4 points. $38^{\circ} \mathrm{C}$ below zero occurred to be critical for buds of 'Ranniy Stolovy' and 'Startovaya'. Sever freezing was noted -4.8 and 3.5 points, respectively. In December and January, all of the studied sea buckthorn genotypes demonstrated frost hardiness of bark (damages from 0 to 0.8 points). In February, the degree of bark damage varied within 1.0 to 2.5 . 'Startovaya' showed the least level of bark frost hardiness in February (damage 2.5 points under $38{ }^{\circ} \mathrm{C}$ below zero). The wood of sea buckthorn genotypes did not show significant damage. ANOVA indicated significant intervarietal differences in water content $\left(\mathrm{F}_{\text {fact }}=\right.$ $9.5>\mathrm{F}_{\text {theor } 0.01}=3.3$ ) and significant difference of level of bud injury in different winter periods $\left(\mathrm{F}_{\text {fact }}=8.8>\right.$ $\left.\mathrm{F}_{\text {theor } 0.01}=5.5\right)$. No significant interactions between those factors were found $\left(\mathrm{F}_{\text {fact }}=0.8>\mathrm{F}_{\text {theor } 0.05}=2.2\right)$.

In January, under stable low temperature there was more bound than available water in annual shoots of four variety samples, which confirmed their frost resistance. The relative amount of bound water was 30.6 to $41.2 \%$ and of available water -5.6 to $16.5 \%$ (Fig. 3). Very high correlation occurred between the amounts of available and bound water $r=-0.97$ in tissue of annual shoots in the middle of winter. ANOVA indicated significant intervarietal differences in the relative amounts of available water $\left(\mathrm{F}_{\text {fact }}=6.5>\right.$ $\left.\mathrm{F}_{\text {theor } 0.01}=3.8\right)$ and bound water $\left(\mathrm{F}_{\text {fact }}=7.1>\mathrm{F}_{\text {theor } 0.01}=\right.$ 6.9)

Immediately after critically negative temperatures $\left(-38^{\circ} \mathrm{C}\right)$, a significant increase of amylase activity was noted in sea buckthorn plants that had passed hardening The ferment activity was higher in male genotypes in the variant "shoots with buds in the phase of green cone" compared to the variant "shoots without hardening": in B 23-34 and Siberian male form No. 1 by 1.85 and 2.82 times, respectively, and in female forms 'Zheltoplodnaya' and 'Surpriz Baltiki' by 1.14 and 1.27 times, respectively. In comparison with the variant "shoots without hardening" the amylase activity increased after freezing at $-38{ }^{\circ} \mathrm{C}$ to a greater degree in male genotypes B 23-34 (by 5.68 times) and Siberian male form No. 1 (by 6.04 times) than in female genotypes 'Zheltoplodnaya' and 'Surpriz Baltiki' (by 3.06 and 5.20 times, respectively). According to the total amylase activity, 'Surpriz Baltiki' and B 23-24 demonstrated the greatest frost resistance (Table 1), similarly as in artificial freezing experiments. One-factor ANOVA showed significant differences in amylase activity in the bark of annual shoots $(p<0.05)$ in all variants of the experiment.

Damage caused by lipid peroxidation (LP) was shown in tests of winter hardiness component II. Increase of malone dialdehyde (MDA) concentration was higher in male forms (by 2.12 and 1.38 times) than in female plants (by 1.23 and 1.25 times). High MDA levels were found in male genotypes in the variant "shoots with buds in the phase of green cone" compared to the variant "shoots without hardening". The increased lipid peroxidase activity in that case indicated more intensive physiological processes in male plants that rapidly broke dormancy (Table 2). One-factor ANOVA showed significant intervarietal difference in malone dialdehyde concentration in bark of annual shoots $(p<0.05)$ in all variants of the experiment.

Regarding fractional water composition in one-year shoots, increase of available water amount occurred after $+2{ }^{\circ} \mathrm{C}$

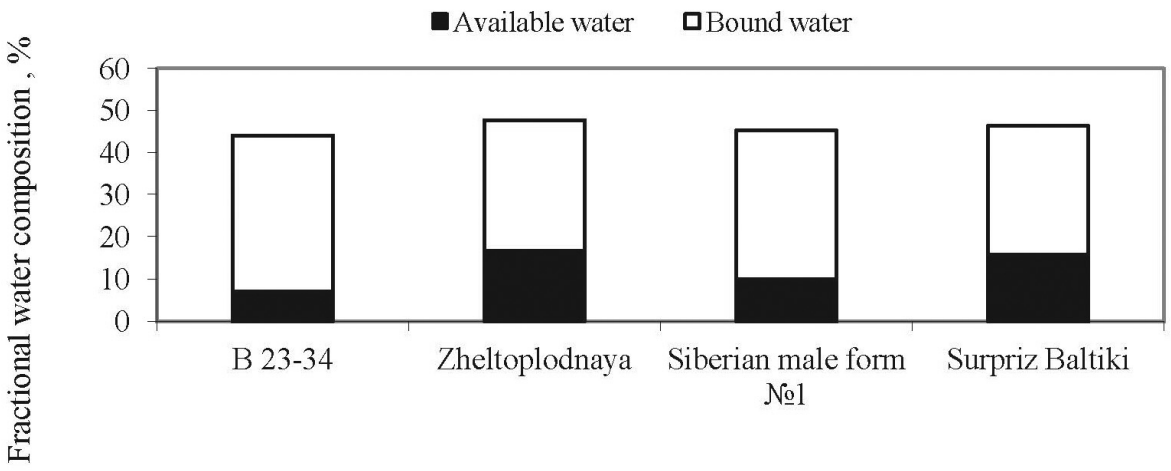

Genotypes
Fig. 3. Fractional composition of water in one-year sea buckthorn shoots in January, \%. 
TOTAL AMYLASE ACTIVITY IN BARK TISSUES OF SEA BUCKTHORN ANNUAL SHOOTS, STARCH mg/g OF FRESH MASS

\begin{tabular}{|c|c|c|c|c|}
\hline \multirow{2}{*}{ Genotype } & \multicolumn{4}{|c|}{ Annual shoots } \\
\hline & $\begin{array}{l}\text { with buds in the phase } \\
\text { of green cone }\end{array}$ & without hardening & $\begin{array}{l}\text { after hardening } \\
\left(-5^{\circ},-10^{\circ} \mathrm{C}\right)\end{array}$ & $\begin{array}{l}\text { after freezing and freezing } \\
\text { at }-38^{\circ} \mathrm{C} \\
\text { (winter hardiness } \\
\text { component II) }\end{array}$ \\
\hline Siberian male form No. 1 & $8.25 \pm 0.30$ & $2.92 \pm 0.09$ & $10.06 \pm 0.34$ & $17.6 \pm 60.70$ \\
\hline B 23-34 & $5.52 \pm 0.18$ & $2.98 \pm 0.10$ & $7.29 \pm 0.29$ & $16.94 \pm 0.63$ \\
\hline Zheltoplodnaya & $5.36 \pm 0.19$ & $4.70 \pm 0.16$ & $6.94 \pm 0.24$ & $14.40 \pm 0.43$ \\
\hline $\mathrm{LSD}_{05}$ & 0.10 & $\begin{array}{l}0.10 \\
0.14\end{array}$ & $\begin{array}{l}1.22 \\
1.84\end{array}$ & $\begin{array}{l}0.70 \\
1.10\end{array}$ \\
\hline
\end{tabular}

Table 2

MALONE DIALDEHYDE CONCENTRATION IN BARK TISSUE OF SEA BUCKTHORN ANNUAL SHOOTS, $\mu$ mol/g

\begin{tabular}{|c|c|c|c|c|}
\hline \multirow[b]{2}{*}{ Genotype } & \multicolumn{4}{|c|}{ Annual shoots } \\
\hline & $\begin{array}{l}\text { with buds in the phase o } \\
\mathrm{f} \text { green cone }\end{array}$ & without hardening & after hardening & $\begin{array}{c}\text { after hardening and freezing } \\
\text { at }-38{ }^{\circ} \mathrm{C} \text { (winter hardiness } \\
\text { component II) }\end{array}$ \\
\hline Siberian male form No. 1 & $4.27 \pm 0.14$ & $4.03 \pm 0.15$ & $8.33 \pm 0.30$ & $8.55 \pm 0.25$ \\
\hline B 23-34 & $6.49 \pm 0.24$ & $6.05 \pm 0.22$ & $6.41 \pm 0.24$ & $8.40 \pm 0.25$ \\
\hline Surpriz Baltiki & $7.10 \pm 0.27$ & $6.95 \pm 0.26$ & $7.18 \pm 0.28$ & $8.60 \pm 0.27$ \\
\hline Zheltoplodnaya & $7.24 \pm 0.25$ & $7.18 \pm 0.25$ & - & $9.00 \pm 0.29$ \\
\hline $\begin{array}{r}\mathrm{LSD}_{05} \\
01\end{array}$ & $\begin{array}{l}0.04 \\
0.07\end{array}$ & $\begin{array}{l}0.12 \\
0.18\end{array}$ & $\begin{array}{l}0.10 \\
0.16\end{array}$ & $\begin{array}{l}0.18 \\
0.27\end{array}$ \\
\hline
\end{tabular}

thaw in all of the genotypes. The increase of available water amount occurred at a lesser degree in female genotypes. The greatest ratio of bound water to available water occurred in 'Surpriz Baltiki' - 1.1 and B 23-34 - 0.9 (Fig. 4). According to the biochemical analysis these genotypes displayed stable frost resistance. High correlation was shown between available and bound water $(r=-0.91)$. One-factor ANOVA showed significant intervarietal difference $\left(\mathrm{F}_{\text {fact }}=\right.$ $\left.2.8>\mathrm{F}_{\text {theor } 0.05}=2.4\right)$ in amounts of available $\left(\mathrm{HCP}_{05}=6.5\right)$ and bound water $\left(\mathrm{HCP}_{05}=7.4\right)$ during thaws.

$25{ }^{\circ} \mathrm{C}$ frosts were modelled after a $+2{ }^{\circ} \mathrm{C}$ three-day thaw (winter hardiness component III) in December, January, February, and March in order to determine the ability of sea buckthorn to retain frost hardiness. 'Zolotaya Kosa', 'Kenigsbergskaya', 'Prima Dona', 'Surpriz Baltiki', and B
23-34 were characterized by stability of one-year shoot bud and tissue frost hardiness under temperature decrease to $-25{ }^{\circ} \mathrm{C}$ after $\mathrm{a}+2{ }^{\circ} \mathrm{C}$ three-day thaw, during the whole winter period. Reversible damages up to 2.0 points were noted. The employed thaw adversely affected the level of bud frost resistance in 'Startovaya', where medium damage of buds (2.6 points) was noted in December; the damages increased up to 3.5 points in January; in February and March buds were severely damaged -4.4 points. The wood of that cultivar had a medium level of frost hardiness in February and March (damage 2.2 points). Buds of the Siberian male form No. 1 were severely damaged in February and March (up to 4.9 points); bud and bark frost hardiness was noted to be decreased to a moderate level (damage 2.7 and 2.3 points) in 'Zheltoplodnaya'. Medium damage of buds (2.6 points) was observed in AB 10-154 male form in March.

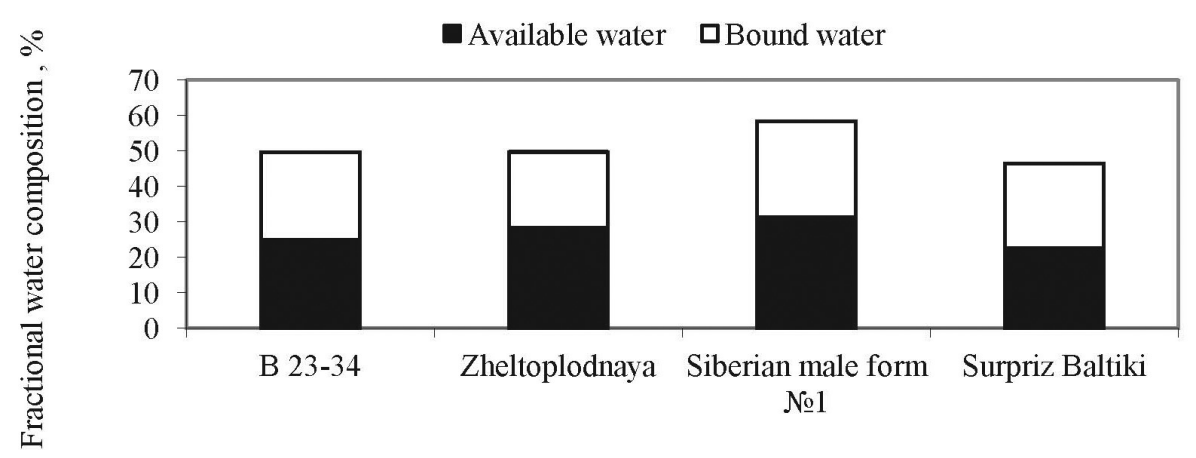

Genotypes
Fig. 4. Fractional water composition in sea buckthorn shoots in January after $+2{ }^{\circ} \mathrm{C}$ thaw $\%$ 
ANOVA indicated significant intervarietal difference in degree of bud injury $\left(\mathrm{F}_{\text {fact }}=26.2>\mathrm{F}_{\text {theor } 0.01}=3.1\right)$ and bark injury $\left(\mathrm{F}_{\text {fact }}=27.1>\mathrm{F}_{\text {theor } 0.01}=2.9\right)$. ANOVA showed no significant intervarietal difference in the degree of wood injury $\left(\mathrm{F}_{\text {fact }}=1.0>\mathrm{F}_{\text {theor } 0.05}=3.0\right)$.

$30{ }^{\circ} \mathrm{C}$ frost was modelled after a $+2{ }^{\circ} \mathrm{C}$ three-day thaw and repeated hardening (winter hardiness component IV) in January, February, and March to determine the ability to restore the frost hardiness of sea buckthorn during winter. The majority of the studied sea buckthorn cultivars were characterized by stability of frost resistance of one-year shoot buds and tissues at temperature up to $+2{ }^{\circ} \mathrm{C}$ and repeated hardening from January to March. Reversible damage up to 2.0 points was noted. The lowest frost hardiness was found in 'Startovaya' and 'Ranniy Stolovy'. The buds of those cultivars severely suffered in February and March. In the Siberian male form No. 1 a medium level of frost hardiness was observed in January and February and severe damage of buds was noted in March. 'Zolotaya Kosa' had a medium level of frost hardiness (frost damages from 2.3 points in January and February to 2.5 points in March). However, tissues of one-year shoots showed ability of repeated hardening after thaw; no significant damage was observed (up to 2.0 points). ANOVA showed significant intervarital difference in the degree of bud injury $\left(\mathrm{F}_{\text {fact }}=17.1>\mathrm{F}_{\text {theor0.01 }}=\right.$ $3.0)$, bark injury $\left(\mathrm{F}_{\text {fact }}=6.9>\mathrm{F}_{\text {theor } 0.01}=3.0\right)$ and wood injury. ANOVA showed intervarital difference in the degree of bud injury $\left(\mathrm{F}_{\text {fact }}=26.2>\mathrm{F}_{\text {theor } 0.01}=3.1\right)$ and bark injury $\left(\mathrm{F}_{\text {fact }}=5.4>\mathrm{F}_{\text {theor } 0.01}=3.0\right)$.

\section{DISCUSSION}

Early in winter an increase of bound water amount is typical for fruit plants. Such changes in water composition play an important role for plant cell survival in frost conditions. In our experiment in one-year shoots of sea buckthorn the quantity of bound water was more than of available water at the beginning of winter. The level of proline contents is considered to be one of the indices of water-holding ability of plant cells. This amino acid together with sugars protects proteins against inactivation in conditions of dehydration and lowers the temperature of freezing of cell sap (Ashraf and Foolad, 2007). In shoots of 'Surpriz Baltiki' and B 23-34, a slight decrease occurred in the proline level after exposure to temperature $-38{ }^{\circ} \mathrm{C}$, which indicated a more stable frost resistance.

Artificial freezing was performed according to the II, III, and IV components of frost hardiness during the whole winter period to determine the dynamics of sea buckthorn winter hardiness. Significant varietal differences were observed in the resistance of buds, bark, and wood of annual sea buckthorn shoots of various ecological and geographical origin. In December, the sea buckthorn genotypes were in deep dormancy, and therefore the highest level of frost hardiness of buds and tissues of annual shoots was observed. During the next months, the frost hardiness of buds and shoot tissues decreased to different degrees when the sea buckthorn plants were in exogenous dormancy. During winter, the maximum frost hardiness was observed in the Baltic climatype cultivars 'Zheltoplodnaya', 'Kenigsbergskaya', 'Serafima', 'Surpriz Baltiki' and male forms AB 10-154, B 23-34; and Siberian genotypes 'Prima Dona' and Siberian male form No. 1. The analysis of biochemical indices (proline contents, amylase activity, malone dialdehyde) showed that under stable negative temperatures (without thaws) male genotype B 23-34 and female 'Surpriz Baltiki' were more resistant to hypothermia. In January, under stable low temperature, there was more bound than available water in shoots in all of the studied four genotypes. This confirmed high winter hardiness of sea buckthorn plants under stable low temperature.

Amylase activity in sea buckthorn was higher in the variant "shoots with buds in the phase of green" compared to the variant "shoots without hardening" in B 23-34 and Siberian male form No. 1 by 1.85 and 2.82 times, respectively, and in female forms 'Zheltoplodnaya' and 'Surpriz Baltiki' by 1.14 and 1.27 times, respectively. Considering the higher values in male forms, there is a greater quantity of sugars as an energetic substrate in male forms and, therefore, a quicker break of male plants from dormancy. Plants that quickly break dormancy during a thaw period are exposed to damage under subsequent negative temperatures. Thus, the female sea buckthorn cultivars demonstrated greater plasticity relative to male forms. Female cultivar 'Surpriz Baltiki' and male genotype B 23-34 showed the greatest frost hardiness according to the activity of total amylase.

Damages caused by lipid peroxidation (LP) were observed in assessment of winter hardiness component II. Increase of malone dialdehyde (MDA) concentration was higher in male forms than in female plants. The relative difference in MDA level between variants "with buds in the phase of green" compared to the variant "shoots without hardening" was also higher in male forms than in female plants. In that case, the increase of LP increase suggests more intensive physiological processes in male sea buckthorn plants, which break more rapidly from dormancy, as suggested from the data on amylase activity.

The performed experiments demonstrated that sharp falls of temperature after thaws during winter can be dangerous for those cultivars that slowly formed winter hardiness. In that case, those cultivars did not pass hardening phases qualitatively and could not reach their maximum frost resistance levels. This can result in bud damage and decrease of productivity. The analysis showed that insufficient bud resistance to frosts after thaws was the most vulnerable aspect in the complex of sea buckthorn winter hardiness. 'Zolotaya Kosa', 'Kenigsbergskaya', 'Surpriz Baltiki', B 23-24, and 'Prima Dona' demonstrated ability to retain frost hardiness after thaw and sharp temperature fall during winter. Female cultivar 'Surpriz Baltiki' and male genotype B 23-34 might be regarded as resistant, according to the concentration of proline, activity of amylase and LP intensity. Those genotypes originated from Baltic sea climatype buckthorn. 
Baltic climatype cultivars 'Zheltoplodnaya', 'Kenigsbergskaya', 'Surpriz Baltiki', B 23-34, and Siberian cultivar 'Prima Dona' were also able to restore frost hardiness after thaw and repeated hardening in different periods of winter.

High frost hardiness of Siberian sea buckthorns has been discussed in multiple reports. In the conditions of the middle zone of horticulture, Siberian sea buckthorn is heterogeneous in winter hardiness, which is confirmed by the results of our study. Siberian sea buckthorn cultivars have a short period of dormancy and under any increase in temperature they start growing, and as a result, buds can be damaged during winter.

Thus, Baltic climatype genotypes 'Kenigsbergaskaya', B 23-34, and Siberian climatype 'Prima Dona' are characterized by stable winter hardiness. These genotypes are recommended as sources for breeding of winter hardiness, as they demonstrated high resistance to critical temperature minimums during the whole winter period according to all of the components of winter hardiness.

\section{REFERENCES}

Ahmad, A., Husain, A., Mujeeb, M., Khan, S. A., Najmi, A. K., Siddique, N. A., Damanhouri, Z. A., Anwar, F. (2013). A review on therapeutic potential of Nigella sativa: A miracle herb. Asian Pac. J. Trop. Biomed., 3 (5). 337-352.

Alojzy, C., Grzegorz, H., Małgorzata, H., Dorota, K. (2004). Susceptibility of one-year-old shoots of scab-resistant apple cultivars to low temperatures in laboratory tests during four winters (1999/2000-2002/2003). Folia Horticulturae, 16 (1), 61-72.

Ashraf, M., Foolad, M. R. (2007). Roles of glycine betaine and proline in improving plant abiotic stress resistance. Environ. Exper. Bot., 59 (2), 206-216.

Baslavskaya, S. S. Trubetzkova, O. M. (1991). Practical Works in Plant Physiology [Баславская, С. С., Трубецкова, О. М. Практикум по физиологии растений]. Moscow. 152 pp. (in Russian).

Bates, L. S., Waldren, R. P., Teare, I. D. (1973). Rapid determination of free proline for water-stress studies. Plant Soil., 39, 205-207.

Bergjord, A. K., Bonesmo, H., Skjelvag, A. O. (2008). Modeling the course of frost tolerance in winter wheat I. Model development. Eur. J. Agron., 28, 321-330.

Chmir, R. A. (2003). Commercial and biological evaluation of sour cherry and sweet cherry in the central zone of Russia [Чмир, Р. А. Хозяйственно-биологическая оценка вишни и черешни в средней полосе России]. Synopsis of Candidate's Thesis. Michurinsk. 22 pp. (in Russian).

Cline, J. A., Neilsen, D., Neilsen, G., Brownlee, R., Norton, D., Quamme, H. (2012). Cold hardiness of new apple cultivars of commercial importance in Canada. J. Amer. Pomological Soc., 66 (4), 174-182.

Dospekhov, В. А. (1985). Methods of the Field Experiment [Доспехов, Б. А. Методика полевого опьта]. Agropromizdat, Moscow. 351 pp.

Fefelov, V. A. (2011). Biological features and breeding of sea buckthorn (Hippophae rhamnoides L.) in the central zone of Russia [Фёфелов, B. А. Биологические особенности и селекция облепихи крушиновидной (Hippophae rhamnoides L.) в средней полосе России]. Synopsis of Doctoral Thesis. Bryansk. 47 pp. (in Russian).

Genisel, M, Turk, H., Erdal, S. (2013). Exogenous progesterone application protects chickpea seedlings against chilling-induced oxidative stress. Acta Physiol. Plant., 35, 241-251.
Khorshidi, M., Sherafatmandjour, A. (2013). Changes of antioxidant properties under estradiol treatment in fennel. Intl. J. Agri. Crop Sci., 5 (21). 2634-2638.

Kichina, V. V. (2011). Principles of Orchard Plant Improvement [Кичина, В. В. Принципы улучшения садовых растений]. Moscow. 528 pp. (in Russian).

Koshkin, E. I. Physiology of Crop Resistance [Кошкин, Е. И. Физиология устойчивости сельскохозяйственных культур]. Moscow. 638 pp. (in Russian).

Mittler, R. (2002). Oxidative stress, antioxidants, and stress tolerance. Trends Plant Sci., 7 (9), 405-409.

Ozherelieva, Z. E., Bogomolova, N. I. (2011). Study of raspberry winter hardiness under modelled conditions [Ожерельева, 3. Е., Богомолова, Н. И. Изучение зимостойкости сортов малины в моделируемых условиях]. In: Fruit and Berry Growing of Russia [Плодоводство и ягодоводство России], Vol. 28, Part 2. Moscow, pp. 107-113 (in Russian).

Ozherelieva, Z. E., Sedov, E. N. (2014). Study of apple winter hardiness under controlled conditions [Ожерельева, 3. Е., Седов, Е. Н. Изучение зимостойкости сортов яблони в контролируемых условиях]. In: Fruit and Berry Growing of Russia [Плодоводство и ягодоводство России], Vol. 30, Part 2. Moscow. 172-175 (in Russian).

Polevoy, A. N., Blyshik, D. V., Feoktistov, P. A. (2015). The modelling of winter hardiness formation by winter wheat plants [Полевой, А. Н., Блыщик, Д. В., Феоктистов, П. А. Моделирование формирования зимостойкости растениями озимой пшеницы]. Problems of Ecological Monitoring and Modelling of Ecosystems [Проблемы экологического мониторинга и моделирования экосистем], 26 (1), 28-48 (in Russian).

Selekhov, V. V, Fefelov, V. A., Igoshina, V. G., Smertin, M. P. (2003). Components of winter resistance in different varieties of sea buckthorn (Hippophae rhamnoides L.). In: Sea buckthorn - a Resource of Health, a Challenge to Modem Technology: Proceedings of the Congress of the International Sea Buckthorn Association, Berlin, p. 51.

Smertin, M. P. (2006). Breeding potential of winter hardiness of sea buckthorn cultivars and hybrids [Смертин, М. П. Селекционный потенциал зимостойкости сортов и гибридов облепихи крушиновидной]. Synopsis of Candidate's Thesis. Bryansk. 23 pp. (in Russian).

Stalnaya, I. D., Garashvili, T. G. (1977). Method of determining malone dialdehyde using thiobarbituric acid [Стальная, И. Д., Гаришвили, Т. Г. Метод определения малонового диальдегида с помощью тиобарбитуровой кислоты]. Contemporary Methods in Biochemistry [Современные методы в биохимии]. Orekhovich, V. N. (Ed.). Moscow, pp. 172-175 (in Russian).

Szalay, L., Timon, B., Nermeth, S., Papp, J., Troth, M. (2010). Hardening and dehardening of peach flower buds. Hortscience, 45 (5), 761-765.

Turina, M. M., Gogoleva, G. A., Efimova, N. V. et. al. Determining of Fruit and Berry Crop Resistance to Stressors of a Cold Season in the Field and Controlled Conditions [Тюрина, М. М., Гоголева, Г. А., Ефимова, Н. В. и др. Определения устойчивости плодовых и ягодных культур к стрессорам холодного времени года в полевых и контролируемых условиях]. Moscow. 120 pp. (in Russian).

Yermakov, A. E. (1987). Methods for Biochemical Investigation of Plants [Ермаков, А. Е. Методы биохимического исследования растений]. Agropromizdat, Leningrad. 429 pp. (in Russian).

Yousfi, N., Slama, I., Ghnaya, T., Savoure, A., Abdelly, C. (2010). Effects of water deficit stress on growth, water relations and osmolyte accumulation in Medicago truncatula and M. laciniata populations. Comptes Rendues Biologies, 333 (3), 205-213.

Zaitzev, G. N. (1984). Mathematical Statistics in Experimental Botany [Зайцев, Г. Н. Математическая статистика в экспериментальной ботанике]. Nauka, Moscow. 424 pp. (in Russian). 
KRIEVIJAS CENTRĀLAJĀ DAḶĀ INTRODUCĒTO SMILTSĒRKŠĶU (Hippophae rhamnoides L.) GENOTIPU SALCIETĪBA

Pētījumā iekḷauti dažādas ekoloğiskās un ğeogrāfiskās izcelsmes smiltsērkšķu genotipi. Izmaiņas ziemas periodā smiltsērkšķu pumpuru un dzinumu audu salcietībā kā arī atškirības škiiņu salcietībā tika noteiktas, izmantojot saldēšanu klimata kamerā kontrolējamos apstākḷos. Lai konstatētu atškirīibas adaptācijas procesā pret zemas temperatūras izraisīto stresu, tika noteikts ūdens frakcionālais sastāvs viengadīgajos dzinumos, prolīna un malona dialdehīda saturs un kopējā amilāzes aktivitāte sievišķo un vīrišķo genotipu mizā. Decembrī, kad visi smiltsērkšḳu genotipi atradās dzị̣ā miera stāvoklī, konstatēta pumpuru un viengadīgo dzinumu visaugstākā salcietība. Turpmākajos mēnešos, kad augi atradās piespiedu miera stāvoklī, pumpuru un viengadīgo dzinumu audu salcietība samazinājās atšḳirīgi, atkarībā no smiltsērkšķu genotipa. Veiktā pētījuma rezultātā kā ziemcietīgākie izdalīti genotipi 'Kenigsbergskaya', 'Surpriz Baltiki', B 23-34 un 'Prima Dona'. Šie genotipi uzrādījuši stabilu salcietību visā ziemas periodā un ir perspektīivi salcietības donori jaunu šḳinnu selekcijā. 